\title{
SOIL PROPERTY CHANGES UNDER DIFFERENT KINDS OF HERBIVORE GRAZING IN ARID RANGELANDS OF YAZD PROVINCE, IRAN
}

\author{
KARIMIAN, A. A. ${ }^{* 1}-$ HOSSEIN JAFARI, S. ${ }^{2}$ \\ ${ }^{1}$ Faculty of Natural Resources and Desert Study, Yazd University, Yazd, Iran \\ ${ }^{2}$ Faculty of Natural Resources, Gorgan University of Agricultural Sciences and Natural \\ Resources, Gorgan, Iran \\ *Corresponding author \\ e-mail:akarimian@yazd.ac.ir
}

(Received $15^{\text {th }}$ Feb 2017; accepted $28^{\text {th }}$ Mar 2017)

\begin{abstract}
Due to the lack of forage and poor condition in arid rangelands, investigation of soil properties is essential and very important. Therefore, the purpose of this study was to compare wildlife, livestock and alternative grazing effects on physicochemical characteristics of the soil in arid rangelands of Kalmand-Bahadoran in Yazd province. Soil samples were taken in each plot $(0-30 \mathrm{~cm})$ and in each site by random systematic method. The results showed that the highest amount of silt and bulk density belonged to livestock grazing site $(\mathrm{p}<0.01)$. Statistical analysis indicated that calcium carbonate percentage in livestock grazing site $(18.33 \%)$ was higher than it was in wildlife+livestock $(14.85 \%)$ and deer $(12.57 \%)$ grazing sites $(\mathrm{p}<0.01)$, respectively. Acidity and electrical conductivity levels in livestock and wildlife+livestock grazing areas were significantly higher than that was in deer grazing site $(\mathrm{p}<0.01)$. Wildlife+livestock grazing area had more organic matters content $(0.28 \%)$ compared to other areas $(\mathrm{p}<0.01)$. P and $\mathrm{K}$ parameters were in the order of livestock > wildlife+livestock > wildlife grazing sites. So that the amount of phosphorus was 79, 71 and 62 and potassium was 101, 87 and 77 in terms of livestock, wildlife+livestock and wildlife grazing sites, respectively. Nitrogen was the highest in alternative grazing area $(0.08 \%)$, wildlife grazing site was in the second level $(0.06 \%)$, and the least amount of Nitrogen was related to livestock grazing region $(0.03 \%)(\mathrm{p}<0.01)$. It can be inferred that there is no negative effects by deer and wildlife+livestock grazing. Proper management strategies should be performed as a tool to reduce some negative impacts.
\end{abstract}

Keywords: Kalmand-Bahadoran, livestock, physicochemical characteristics, range management, wildlife

\section{Introduction}

Rangelands are one of the most important ecosystems in the world which supply forage for wildlife and livestock (MacNeil et al., 2008). Rangelands sustainability is affected by several factors interaction such as organisms (herbivores), climatic and edaphic parameters (Heidarian Aghakhani et al., 2010; Speed and Austrheim, 2017). So, managing herbivores and vegetation interactions shows how soil and water resources are managed (Afrah et al., 2010).Generally, different grazing regimes can effect soil physiochemical characteristics ( $\mathrm{Li}$ et al., 2017). Grazing by wild and domestic ungulates causes soil deformation by trampling and soil compaction (Yong-Zhong et al., 2005; Zhao et al., 2007; Kumbasli et al., 2010), and if grazing pressure increases, it will lead to rangeland degradation (Sandhage-Hofmann et al., 2015). Livestock grazing is usually guided by human (Ruiz-Mirazo, 2011) but wildlife freely move in rangelands (Fynn, 2012). Therefore, Grazing by wild ungulates naturally differs from livestock grazing (Jackson and Bartolome, 2007). Depending on the number of stocking rate, ungulate type (wild or domestic) and grazing periods, grazing practices affect soil properties 
(Sanjari et al., 2008; Hossein Jafari et al., 2014), and with proper managed programs it may have positive effect on soil characteristics (Vavra, 2005).

Wildlife and livestock grazing has positive or negative effects on soil characteristics in rangeland ecosystems (McDowell et al., 2004; Steffens et al., 2008; Zarekia et al., 2012; Hossein Jafari et al., 2014; Matano et al., 2015). High grazing intensity leads to decreasing nutrient availability resulting in soil fertility reduction (Morgan, 1995; Hiernaux et al., 1999; Connolly et al., 2016).

Based on literature review there are a few studies about comparing the effect of livestock and wildlife grazing on soil characteristics in rangelands (Parissi et al., 2014; Hossein Jafari et al., 2014). Kalmand-Bahadoran as an arid rangeland is important for wildlife conservation and livestock grazing. According to lack of forage and poor condition in arid rangelands, investigating soil properties is essential and very important. Therefore, the purpose of this study was to compare wildlife, livestock and alternative grazing effects physicochemical properties of the soil in arid rangelands of Kalmand-Bahadoran in Yazd province. This study focused on this hypothesis that three grazing management regimes change soil characteristics, but not essentially negatively. The results can help to find critical thresholds of grazing pressure on KalmandBahadoran rangeland.

\section{Materials and methods}

This study was carried out in Kalmand-Bahadoran Arid Rangeland, at 1400 to 3290 $\mathrm{m}$ above sea level with $100 \mathrm{~mm}$ average annual precipitation (at $31^{\circ} 00^{\prime}$ to $31^{\circ} 40^{\prime} \mathrm{N}$ and $54^{\circ} 15^{\prime}$ to $55^{\circ} 20^{\prime}$ E). This area is located near Mehriz in Yazd Province, Iran (Karimian, 1999; Consulting engineers of Iran, 2002).

Three sites were selected in Kalmand-Bahadoran Rangeland in order to comparing the effects of livestock, wildlife and wildlife+livestock alternative grazing on soil properties. Three regions were selected for soil sampling based on topographic maps and field investigation (Hossein Jafari et al., 2014). Two regions were in protected area and under wildlife (deer) and deer+sheep and goat alternative grazing. The other was outside the protected area, under livestock (sheepand goat) grazing.

Soil samples were taken from the top soil $(0-30 \mathrm{~cm})$ in each plot and each site. Soil sampling was conducted based on random systematic method. 15 random transects of $100 \mathrm{~m}$ were placed in three sites. Soil samples were systematically taken from the first and at the end of each transect (30 samples from each site). In the laboratory, bulk density (by cylinder method) and soil texture (by hydrometric method) were measured. Acidity and electrical conductivity were determined using $\mathrm{pH}$ meter and EC meter in saturated mud. To measure organic matters, Walkley-Block method was used. Moisture and Calcium carbonate were determined by Oven and titration method respectively. The contents of $\mathrm{N}, \mathrm{P}$ and $\mathrm{K}$ were determined by atomic absorption spectrometry (Jafari Haghighi, 2003). Data analysis was performed by ANOVA test using SPSS Software.

\section{Results}

The results of comparing physical parameters demonstrate that there is a significant difference in silt percentage $(\mathrm{p}<0.05)$ and bulk density $(\mathrm{p}<0.01)$ in different areas. The highest amount of silt is observed in livestock site $(11.45 \%)$, but there is no difference between deer $(6.43 \%)$ and deer+livestock $(5.84 \%)$ grazing areas. The highest bulk 
density belongs to livestock site $\left(0.98 \mathrm{gr} / \mathrm{cm}^{2}\right)$. Wildlife+livestock grazing region is in the second level $\left(0.75 \mathrm{gr} / \mathrm{cm}^{2}\right)$. Wildlife site has the least amount of bulk density $(0.70$ $\left.\mathrm{gr} / \mathrm{cm}^{2}\right)(\mathrm{p}<0.01)$. There is no obvious difference among three regions in terms of sand, clay and moisture percentages (Table 1).

Table 1. Comparing soil physical parameters among three regions under wildlife, livestock and wildlife+livestock alternative grazing using ANOVA test

\begin{tabular}{|c|c|c|c|c|c|c|}
\hline $\begin{array}{c}\text { Soil texture } \\
\text { parameters }(\%)\end{array}$ & Study site & Average & $\begin{array}{l}\text { Mean } \\
\text { Square }\end{array}$ & df & $\mathrm{F}$ & Significant \\
\hline \multirow{3}{*}{ Sand } & Wildlife & 79.873 & \multirow{3}{*}{20.291} & \multirow{3}{*}{89} & \multirow{3}{*}{1.109} & \multirow{3}{*}{$0.389^{\mathrm{ns}}$} \\
\hline & Wildlife + Livestock & 81.713 & & & & \\
\hline & Livestock & 76.580 & & & & \\
\hline \multirow{3}{*}{ Silt } & Wildlife & $6.427 \mathrm{~b}$ & \multirow{3}{*}{28.561} & \multirow{3}{*}{89} & \multirow{3}{*}{5.839} & \multirow{3}{*}{$0.039^{*}$} \\
\hline & Wildlife + Livestock & $5.840 \mathrm{~b}$ & & & & \\
\hline & Livestock & $11.453 \mathrm{a}$ & & & & \\
\hline \multirow{3}{*}{ Clay } & Wildlife & 13.700 & \multirow{3}{*}{2.403} & \multirow{3}{*}{89} & \multirow{3}{*}{0.389} & \multirow{3}{*}{$0.694^{\mathrm{ns}}$} \\
\hline & Wildlife + Livestock & 12.447 & & & & \\
\hline & Livestock & 11.967 & & & & \\
\hline \multirow{3}{*}{ Moisture (\%) } & Wildlife & 1.020 & \multirow{3}{*}{0.002} & \multirow{3}{*}{89} & \multirow{3}{*}{0.818} & \multirow{3}{*}{$0.485^{\mathrm{ns}}$} \\
\hline & Wildlife + Livestock & 1.040 & & & & \\
\hline & Livestock & 0.993 & & & & \\
\hline \multirow{3}{*}{$\begin{array}{c}\text { Bulk } \\
\text { density }\left(\mathrm{gr} / \mathrm{cm}^{2}\right)\end{array}$} & Wildlife & $0.703 \mathrm{c}$ & \multirow{3}{*}{0.066} & \multirow{3}{*}{89} & \multirow{3}{*}{26.923} & \multirow{3}{*}{$0.000^{* *}$} \\
\hline & Wildlife + Livestock & $0.750 \mathrm{~b}$ & & & & \\
\hline & Livestock & $0.980 \mathrm{a}$ & & & & \\
\hline
\end{tabular}

$\left({ }^{\text {ns: }}\right.$ No significant $\left.),\left({ }^{*} \mathrm{P}<0.05\right),{ }^{* *} \mathrm{P}<0.01\right)$

The results show that there is a significant difference among three regions in terms of soil chemical parameters (Table 2). Statistical analysis indicates that calcium carbonate percentage in livestock site $(18.33 \%)$ was higher than wildlife+livestock $(14.85 \%)$ and deer $(12.57 \%)$ grazing areas $(\mathrm{p}<0.01)$, respectively. According to Table 2, acidity and electrical conductivity are equal statistically in livestock and wildlife+livestock areas. These parameters are significantly higher than that was in deer site $(\mathrm{p}<0.01)$.

Wildlife+livestock grazing area has higher organic matters $(0.28 \%)$ compared to other areas. There is no significant difference between livestock $(0.21 \%)$ and deer $(0.22 \%)$ grazing sites in terms of organic matters $(\mathrm{p}<0.01)$.

$\mathrm{P}$ and $\mathrm{K}$ parameters are in the order of livestock $>$ wildlife+livestock $>$ wildlife grazing sites. So that the amount of phosphorus is 79, 71 and 62 and potassium is 101, 87 and 77 in terms of livestock, wildlife+livestock and wildlife sites, respectively. Nitrogen parameter with $0.08 \%$ is the highest in wildlife+livestock alternative grazing area. Wildlife site was in the second level $(0.06 \%)$, and the least amount of Nitrogen was related to livestock grazing region $(0.03 \%)(\mathrm{p}<0.01)($ Table 2$)$. 
Table 2. Comparing soil chemical parameters among three regions under wildife, livestock and wildlife+livestock alternative grazing using ANOVA test

\begin{tabular}{|c|c|c|c|c|c|c|}
\hline $\begin{array}{l}\text { Soil texture } \\
\text { parameters }\end{array}$ & Study site & Average & $\begin{array}{l}\text { Mean } \\
\text { Square }\end{array}$ & df & $\mathrm{F}$ & Significant \\
\hline \multirow{3}{*}{$\begin{array}{c}\text { Calcium } \\
\text { carbonate }(\%)\end{array}$} & Wildlife & $12.573 \mathrm{c}$ & \multirow{3}{*}{25.216} & \multirow{3}{*}{89} & \multirow{3}{*}{46.878} & \multirow{3}{*}{$0.000^{* *}$} \\
\hline & Wildlife + Livestock & $14.850 \mathrm{~b}$ & & & & \\
\hline & Livestock & $18.330 \mathrm{a}$ & & & & \\
\hline \multirow{3}{*}{ Acidity } & Wildlife & $7.839 \mathrm{~b}$ & \multirow{3}{*}{0.364} & \multirow{3}{*}{89} & \multirow{3}{*}{18.247} & \multirow{3}{*}{$0.003^{* *}$} \\
\hline & Wildlife + Livestock & $8.360 \mathrm{a}$ & & & & \\
\hline & Livestock & $8.500 \mathrm{a}$ & & & & \\
\hline \multirow{3}{*}{$\begin{array}{c}\text { Electrical } \\
\text { conductivity } \\
(\mathrm{ds} / \mathrm{m})\end{array}$} & Wildlife & $0.775 \mathrm{~b}$ & \multirow{3}{*}{0.409} & \multirow{3}{*}{89} & \multirow{3}{*}{45.056} & \multirow{3}{*}{$0.000^{* *}$} \\
\hline & Wildlife + Livestock & $1.350 \mathrm{a}$ & & & & \\
\hline & Livestock & $1.463 \mathrm{a}$ & & & & \\
\hline \multirow{3}{*}{$\begin{array}{l}\text { Organic matters } \\
\qquad(\%)\end{array}$} & Wildlife & $0.220 \mathrm{~b}$ & \multirow{3}{*}{0.004} & \multirow{3}{*}{89} & \multirow{3}{*}{25.800} & \multirow{3}{*}{$0.001 * *$} \\
\hline & Wildlife + Livestock & $0.280 \mathrm{a}$ & & & & \\
\hline & Livestock & $0.210 \mathrm{~b}$ & & & & \\
\hline \multirow{3}{*}{$\mathrm{N}(\%)$} & Wildlife & $0.063 \mathrm{~b}$ & \multirow{3}{*}{0.001} & \multirow{3}{*}{89} & \multirow{3}{*}{44.33} & \multirow{3}{*}{$0.000^{* *}$} \\
\hline & Wildlife + Livestock & $0.077 \mathrm{a}$ & & & & \\
\hline & Livestock & $0.033 \mathrm{c}$ & & & & \\
\hline \multirow{3}{*}{$\mathrm{P}(\mathrm{mg} / \mathrm{kg})$} & Wildlife & $62.00 \mathrm{c}$ & \multirow{3}{*}{217.0} & \multirow{3}{*}{89} & \multirow{3}{*}{31.00} & \multirow{3}{*}{$0.001^{* *}$} \\
\hline & Wildlife + Livestock & $71.00 \mathrm{~b}$ & & & & \\
\hline & Livestock & $79.00 \mathrm{a}$ & & & & \\
\hline \multirow{3}{*}{$\mathrm{K}(\mathrm{mg} / \mathrm{kg})$} & Wildlife & $77.00 \mathrm{c}$ & \multirow{3}{*}{436.0} & \multirow{3}{*}{89} & \multirow{3}{*}{62.286} & \multirow{3}{*}{$0.000^{* *}$} \\
\hline & Wildlife + Livestock & $87.00 \mathrm{~b}$ & & & & \\
\hline & Livestock & $101 \mathrm{a}$ & & & & \\
\hline
\end{tabular}

$\left({ }^{\mathrm{ns}}\right.$ : No significant $),\left({ }^{*} \mathrm{P}<0.05\right),\left({ }^{* *} \mathrm{P}<0.01\right)$

\section{Discussion and conclusions}

The results demonstrated that silt percentage increased significantly in livestock grazing area compared to other sites. Sand and clay percentages decreased in livestock site but it was not obvious statistically. The reason for these differences might be changes in soil natural structure. The protected area is near to the mountains which are susceptible to erosion. Ajorlou (2007) and Hossein Jafari et al. (2014) announced that the reason for soil texture changes is sand transition from surrounding areas. Huang et al. (2007), Du to Kumbasli et al. (2010) and Cournane et al. (2011) also found similar results in their studies. They confirmed that the main reason for changes in soil particle composition is soil wind erosion.

The results revealed that the highest and the least amount of bulk density was related to livestock and wildlife sites, respectively. Totally, livestock grazing behaviour is different from wildlife (Speed and Austrheim, 2017). Livestock prefer to graze more concentrate than wildlife, while deer like to graze far from each other. In addition, livestock is conducted by a manager and does not graze freely in rangelands (Speed and 
Austrheim, 2017). This cause livestock has more pressure on soil and increase bulk density. But deer grazing area had the least amount of bulk density. Hossein Jafari et al. (2014) confirmed this issue in their studies. Other researchers confirmed that higher bulk density is due to increasing soil compaction and animal trampling (Brevik et al., 2002; Binkley et al., 2003; Hamza and Anderson, 2005). Increasing soil calcium carbonate and acidity is also due to high pressure in livestock grazing area. Livestock make bottom carbonate layer closer to the surface by soil layers degradation and cause a significant increase in soil calcium carbonate and acidity (Dormaar, 1998; Hossein Jafari et al., 2014).

Electrical conductivity had also a significant reduction in wildlife grazing area. When deer graze halophyte species, does not let plants residue and matters return to the soil. Therefore, it causes a reduction in soil salinity. This result is similar to (Ajorlou et al., 2011 and Zarekia et al., 2012) studies.

According this study results, organic matter percentages were low in three areas. In arid regions, high distances between plants and lack of vegetation can cause decreasing organic matter (Hossein Jafari et al., 2014). The results indicated that soil organic matter content has a significant increase in wildlife+livestock alternative grazing site. In this area, returning organic matters to the soil is higher than other areas. It seems that vegetation type and density leading to some changes in soil organic matters. Other studies announced that reducing soil organic matters decrease microorganisms activity and organic matters breaking down less than usual (Xie and Witting, 2004; Jalilvand et al., 2007). Sandhage-Hofmann et al. (2015) announced that when plants residues like litter, leaf and stem fall return to the soil, fertility enhances. According to the results, there is a linear relationship between organic matter and nitrogen. In other word, increased organic matter increases the amount of nitrogen. Many researchers refer to this relationship in their studies (Pei et al., 2008; Hosseinzadeh et al., 2010; Kumbasli et al., 2010). They announced that the reason is vegetation removal by herbivores. Schuman et al. (1999) revealed that the main reason for none increasing soil organic carbon and nitrogen is non-breaking and mixing plant residues with the soil. The results of $\mathrm{Li}$ et al. (2017) research in alpine meadow showed that exclusion enhanced $\mathrm{C}$ and $\mathrm{N}$ storage in soil via promoting grasses root system and their growth.

The results indicated that soil phosphorous was affected by grazing and its amount in livestock grazing site was higher than the other sites. It seems that high grazing pressure increased soil phosphorus level. This result is similar to those of Jusoff (1988); Javadi et al. (2006); Kohandel et al. (2006); Zarekia et al. (2012) studies. According to moisture deficiency in all three grazing sites, increasing the amount of soil phosphorus in livestock grazing site can be due to livestock dung and trampling which enhances the move ability of the phosphorus in soil. Haynes and Williams (1993) indicated that 65\% of phosphorus in diet consumed by cow returned to the soil. The results of Garcia et al. (2011) study did not follow our results. They revealed that phosphorus level in nongrazed area was higher than grazed area in a rangeland with subtropical climate. They said that the reason may have been due to climate conditions and soil fertility.

Based on the results, soil potassium was higher in livestock grazing area compared to other sites. This can be also due to more livestock trampling and their excreta. The results are similar to several studies who reported that $\mathrm{K}$ level raised significantly in the site with successive grazing (Javadi et al., 2006; Kohandel et al., 2006; Garcia et al., 2011; Zarekia et al., 2012). Haynes and Williams (1993) stated that increasing $\mathrm{K}$ in the site under cow grazing is more due to animal urine than animal dung. 
Soil parameters like bulk density, $\mathrm{pH}, \mathrm{EC}$, organic matters, Calcium carbonate, $\mathrm{N}, \mathrm{P}$ and $\mathrm{K}$ were good indicators of grazing management. It can be inferred that there is no negative effects by deer and wildlife+livestock grazing. Livestock grazing cause soil changes more than two other grazing site. Proper management strategies should be performed as a tool to reduce some negative impacts.

\section{REFERENCES}

[1] Afrah, H., Barani, H., Bahremand, A., Sheikh, V. (2010): Comparison of soil physical properties in micro terraces and inters micro terraces on rangelands (Case study: Baba Shamlak Ranch). - Journal of Water and Soil Conservation 17 (2): 141-153.

[2] Ajorlo, M. (2007): Effects of distance from critical points on the soil and vegetation characteristics of rangelands. - Pajouheshand Sazandegi 74: 170-174. (in Persian)

[3] Ajorlo, M., Abdullah, R., Hanif, A.H.M., Halim, R.A., Yusoff, M.K. (2011): Impacts of livestock grazing on selected soil chemical properties in intensively managed pastures of Peninsular Malaysia.- Journal of Tropical Agricultural Science, 34: 109-121.

[4] Binkley, D., Singer, F., Kaye, M., Rochelle, R.m. (2003): Influence of elk grazing on soil properties in Rocky Mountain National Park. - Forest Ecology and Management 185 (3): 239-247.

[5] Brevik, E., Fenton, T., Moran, L. (2002): Effect of soil compaction on organic carbon amounts and distribution, South-Central lowa.- Environmental Pollution 116: S137S141.

[6] Connolly, B.M., Orrock, J.L., Witter, M.S. (2016): Soil condition moderate the effects of herbivores, but not mycorrhizae, on a native bunchgrass. - Acta Oecologica 77: 100-108.

[7] Consulting engineers of Iran (2002): Management project of Kalmand-Bahadoran protected area, 14 Vol., (vegetation section) 180pp. (In Persian)

[8] Cournane, F.C., Mc Dowell, R., Littlejohn, R., Condron, L. (2011): Effects of cattle, sheep and deer grazing on soil physical quality and losses of phosphorus and suspended sediment losses in surface runoff. - Agriculture, Ecosystems and Environment 140 (2): 264- 272.

[9] Dormaar, J.F., Smoliak, S. andWillms, W.D. (1998): Vegetation and soil responses to short duration grazing on Fescue grasslands. - Journal of Range Management 42 (3): 252256.

[10] Fynn, R.W.S. (2012): Functional Resource Heterogeneity Increases Livestock and Rangeland Productivity. - Rangeland Ecology and Management 65: 319-329.

[11] Garcia, M.R.L., Sampaio, A.A.M., Nahas, E. (2011): Impact of different grazing systems for bovine cattle on the soil microbiological and chemical characteristics. - Revista Brasileira de Zootecnia 40 (7): 1568-1575.

[12] Hamza, M.A., Anderson, W.K. (2005): Soil compaction in cropping systems-a review of the nature, causes and possible solutions. - Soil and Tillage Research 47 (3-4): 291-302.

[13] Haynes, R., Williams, P. (1993): Nutrient cycling and soil fertility in the grazed pasture ecosystem. - Advances in Agronomy 49 (1): 19-199.

[14] Huang D., Wang K., Wu W.L. (2007): Dynamics of soil physical and chemical properties and vegetation succession characteristics during grassland desertification under sheep grazing in an agro-pastoral transition zone in Northern China. - Journal of Arid Environ. 70: 120- 136. 
[15] HeidarianAghakhani, M., NaghipourBorj, A.A., Tavakoli, H. (2010): The effects of grazing intensity on vegetation and soil in Sisab rangelands, Bojnord, Iran.- Iranian Journal of Range and Desert Research 17(2): 243-255. (In Persian)

[16] Hiernaux, P., Bielders, C.L., Valentin, C., Bationo, A., Fernández-Rivera, S. (1999): Effects of livestock grazing on physical and chemical properties of sandy soils in Sahelian rangelands. - Journal of Arid Environments 41 (3): 231-245.

[17] HosseinJafari, S., Tatian, M.R., Tamartash, R., Karimian, A.A. (2014): Wildlife and Livestock Grazing Effects on Some Physical and Chemical Soil Properties (Case Study: Kalmand-Bahadoran Arid Rangelands of Yazd Province). - Journal of Desert 19-1: 57-63.

[18] Hosseinzadeh, G., Jalilvand, H., Tamartash, R. (2010): Short time Impact of Enclosure on Vegetation Cover, Productivity and some Physical and Chemical Soil Properties. Journal of Applied Science 10: 2001-2009.

[19] Jackson, R.D., Bartolome, J. W. (2007): Ecology and management of California grasslands. - In: Corbin, J., Stromberg, M., D’Antonio, C.M. (eds). Chapter 15: Grazing ecology of California grasslands: 1-41. UC Press.

[20] JafariHaghighi, M. (2003): Soil analysis, sampling and important physical and chemical analysis method with emphasis on theory and application basics. - Nedayezoha press, $240 \mathrm{p}$.

[21] Jalilvand, H., Tamartash, R., Heydarpour, H. (2007): Grazing impact on vegetation and some soil chemical properties in Kojour Rangelands, Noushahr, Iran. - Journal of Rangeland 1: 5366. (in Persian)

[22] Javadi, S., Jafari, M., Azarnivand, H., Zahedi, G. (2006): Investigation on grazing upon soil parameters at Lar summer rangeland. - Journal of Agricultural Sciences 11 (4): 71-78.

[23] Jusoff, K. (1988): Influence of sheep grazing on soil chemical properties and growth of rubber (Jeveabrasiliensis) in Malaysia. - Agroforestry Systems 7 (2): 115-120.

[24] Karimian, A.A. (1999): Investigation and identification of plant speciesin KalmandBahadoran protected area. - Study project of environment, 90pp. (In Persian)

[25] Kohandel, A., Arzani, H., HosseiniTavassol, M. (2006): Effect of grazing intensity on N.P.K os soil. - Iran-Watershed management Science and Engineering 3 (6): 59-65.

[26] Kumbasli, M., Makineci, E., Cakir, M. (2010): Long term effects of red deer (Cervuselaphus) grazing on soil in a breeding area. - Journal of Environmental Biology 31: $185-188 \mathrm{pp}$.

[27] Li, W., Cao, W., Wang, J., Li, X., Xu, Ch., Shi, Sh. (2017): Effects of grazing regime on vegetation structure, productivity, soil quality, carbon and nitrogen storage of alpine meadow on the Qinghai-Tibetan Plateau. - Ecological Engineering 98: 123- 133.

[28] MacNeil, M.D., Haferkamp, M.R., Vermeire, L.T., Muscha, J.M. (2008): Prescribed fire and grazing effects on carbon dynamics in a northern mixed-grass prairie. - Journal of Agriculture, Ecosystems and Environment 127: 66-72.

[29] Matano, A.S., Kanangire, C.K., Anyona, D.N., Abuom, P.O., Gelder, F.B., Dida, G.O., Owuor, P.O., Ofulla. A.V.O. (2015): Effects of land use change on land degradation reflected by soil properties along Mara River, Kenya and Tanzania. - Open Journal of Soil Science 5: 20-38.

[30] Mc Dowell, R.W., Drewry, J.J., and Paton, R.J. (2004): Effects of deer grazing and fenceline pacing on water and soil quality. - Journal of Soil use and management 20: 302- 307.

[31] Morgan, R.P.C. (1995): Soil Erosion and Conservation. 2nd Edition. - Longman Group, Essex. P: 295. 
[32] Parissi, Z.M., A. Papaioannou, E.M. Abraham, A.P. Kyriazopoulos, P. Sklavou, Tsiouvaras, C.N. (2014): Influence of combined grazing by wild boar and small ruminant on soil and plant nutrient contents in a coppice oak forest. - Journal of Plant Nutrition and Soil Science 177: 783-791.

[33] Pei, S., Fu, H., Wan, C. (2008): Changes in soil properties and vegetation following exclosure and grazing in degraded Alxa desert steppe of Inner Mongolia. - China. Agriculture, Ecosystem and Environment 124 (1): 33-39.

[34] Ruiz-Mirazo, J. (2011): Environmental benefits of extensive livestock farming: wildfire prevention and beyond. - Options Méditerranéennes 100: 75-82.

[35] Sandhage-Hofmann, A., Kotze, E., van Delden, L., Dominiak, M., Fouche, H., Westhuizen, H.C., Onmen, R.J., Preez, C.C., Amelung, W. (2015): Rangeland management effects on soil properties in the savannah biome, South Africa: A case study along grazing gradients in communal and commercial farms. - Journal of Arid Environment 120: 14-25.

[36] Sanjari, G., Ghadiri, H., Ciesiolka, C. A. A., Yu, B. (2008): Comparing the effects of continuous and time-controlled grazing systems on soil characteristics in Southeast Queensland. - Australian Journal of Soil Research 46: 348-358.

[37] Schuman, G., Reeder, J., Manley, J., Hart, R., Manley, W. (1999): Impact of grazing management on the carbon and nitrogen balance of a mixed-grass rangeland. - Ecological Applications 9 (1): 65-71.

[38] Speed, J.D.M., Austrheim, G. (2017): The importance of herbivore density and management as determinants of the distribution of rare plant species. - Biological Conservation 205: 77-84.

[39] Steffens, M., Kolbl, A., Totsche, K.U., Kogel-Knabner, I. (2008): Grazing effects on soil chemical and physical properties in a semiarid steppe of Inner Mongolia (P.R. China). Geoderma 143: 63- 72.

[40] Vavra, M. (2005): Livestock grazing and wildlife: developing compatibilities. Rangeland Ecology and Management 58:128-134.

[41] Xie, Y., Wittig, R. (2004): The impact of grazing intensity on soil characteristics of Stipagrandis and Stipabungeana steppe in northern China (autonomous region of Ningxia). - ActaOecol, 25: 197- 204.

[42] Yong-Zhong, S., Yu-Lin, L., Jian-Yuan, C., Wen-Zhi, Z.h. (2005): Influences of continuous grazing and livestock exclusion on soil properties in a degraded sandy grassland, Inner Mongolia, northern China. - Catena 59: 267-278.

[43] Zarekia, S., Jafari, M., Arzani, H., Javadi, S.A., Ashraf Jafari, A. (2012): Grazing Effects on Some of the Physical and Chamical Properties of Soil. - World Applied Sciences Journal 20 (2): 205-212.

[44] Zhao, Y., Peth, S., Krummelbein, J., Horn, R., Wang, Z., Steffens, M., Hoffmann, C., Peng, X. (2007): Spatial variability of soil properties affected by grazing intensity in Inner Mongolia grassland. - Ecol. Model. 205: 241-254. 